\title{
A Characterization of the Delaware Sea Breeze Using Observations and Modeling
}

\author{
Christopher P. Hughes ANd Dana E. Veron \\ Department of Geography, College of Earth, Ocean, and Environment, University of Delaware, Newark, Delaware
}

(Manuscript received 30 June 2017, in final form 10 April 2018)

\begin{abstract}
Sea-breeze circulations are a prominent source of diurnal wind variability along coastlines throughout the world. For Delaware, the sea breeze is the largest source of variability in the coastal wind field. We developed a detailed, year-round sea-breeze climatology for the Delaware coastline using 9 years of meteorological station data and an objective sea-breeze detection algorithm. Sea-breeze fronts were identified and characterized by timing, speed, and duration as well as the resulting temperature and humidity changes. The observed temperature change associated with the Delaware sea-breeze front varied spatially, as well as with season, time of day, location, and developmental stage of the front. The observed sea breeze also had some unique features because of the location of southern Delaware on the Delmarva Peninsula and the complicated shape of the local coastline. Details of the summertime sea breeze were further explored using simulations with the Weather Research and Forecasting Model for June-August of 2000-09. Model-simulated sea-breeze characteristics were then compared with the observed sea-breeze climatology whenever possible. Results suggest that the mesoscale atmospheric model is capable of simulating the complex, observed spatial and temporal characteristics of the Delaware Sea breeze. However, the sea breeze in the model was weaker than that observed and tended to dissipate earlier in the afternoon, making it a challenging phenomenon to detect and characterize in the model. Improved detection and simulation of the sea-breeze fronts will increase our understanding of the impact this regional phenomenal has on the local climate and on the populations living by the coast.
\end{abstract}

\section{Introduction}

Sea-breeze circulations are mesoscale, thermally driven systems that frequently impact the coastal climate. Sea breezes are experienced by communities located along ocean coastlines, home to approximately $39 \%$ of the population of the United States in addition to hosting millions of tourists annually (U.S. Census Bureau 2011). A sea-breeze circulation can develop when there is a horizontal, atmospheric surface temperature gradient that creates a surface pressure gradient, with relatively high pressure over the sea and lower pressure over the land (Simpson 1994). These conditions allow advection of cool marine air inland where it collides with warmer terrestrial air creating the sea-breeze front. This land-sea temperature gradient tends to be largest in the summer months, when sea breezes are more likely to occur (Simpson 1994; Sikora et al. 2010).

The air temperature difference over land and sea required for sea-breeze development has been shown to be affected by the prevailing winds and the local topography,

Corresponding author: Dana E. Veron, dveron@udel.edu including the size of the surrounding water mass (Biggs and Graves 1962). Delaware is an interesting location for sea breezes because of its shape and complex coastline, which both influence sea-breeze development and movement. For example, a narrow landmass, like that of the Delmarva Peninsula, allows for the occasional development of two sea breezes, one on each coast, which then can converge in the middle (Xian and Pielke 1991). The Delmarva Peninsula is a relatively small area that is $274 \mathrm{~km}$ long and $113 \mathrm{~km}$ wide at the widest point and is bordered by the Atlantic Ocean and the Chesapeake and Delaware Bays. As such, the Delaware sea breeze can originate from the Atlantic coast, the Delaware Bay coast, or both. For example, the meteorological station at Lewes, Delaware, situated in southeastern Delaware near the mouth of the Delaware Bay (Fig. 1), frequently experiences two distinct sea-breeze fronts, originating from the Delaware Bay and Atlantic Ocean, respectively.

Furthermore, the peninsula has very complex topography, with curved coastlines and numerous small inlets that can influence sea-breeze propagation. For example, Gilliam et al. (2004) found that the convex shape of the 


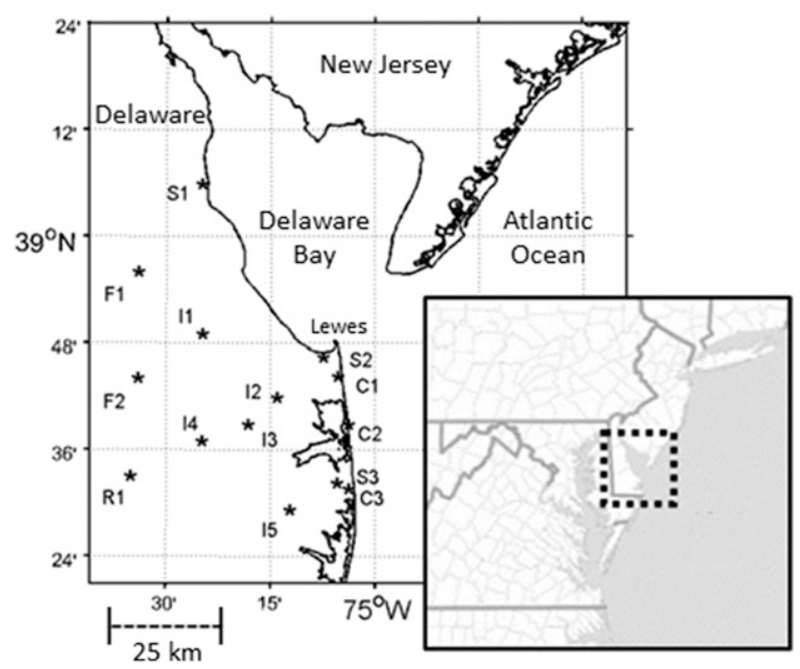

FIG. 1. Location of DEOS and NDBC meteorological stations of interest. The first letter of each station identifier corresponds as $\mathrm{C}$ : coastal, S: semicoastal, I: inland, F: far inland, and R: reference. The stations are numerically ordered from north to south. The dotted line indicates the approximate location of the inner domain used for the model runs.

North Carolina coastline enhances convergence and uplift, thus increasing cloud production along the sea-breeze front. The combined ocean and bay coastline of Delaware is relatively convex, which may increase convergence associated with a sea-breeze front as it moves inland from the Delaware coastline across the Delmarva Peninsula.

In addition, the land cover of southern Delaware is varied, including cities, suburbs, state parks, inland bays, marshland, and farmland (NOAA 2018). Near Delaware's coastline, sea surface temperatures are variable over seasonal, monthly, and diurnal time scales and are often modified by upwelling events during the summer (Whitney and Garvine 2006; Voynova et al. 2013). The upwelling of cold water can enhance the land surface temperature gradient required to generate a sea breeze. Spatial diversity of surface properties affects the development and movement of the sea-breeze circulation as has been seen in both observational and modeling studies (Franchito et al. 1998; Chen et al. 2011).

Synoptic conditions can also influence the development and motion of a sea-breeze front. For example, a study by Savijärvi and Alestalo (1988) showed that strong onshore flow $\left(>5 \mathrm{~m} \mathrm{~s}^{-1}\right)$ weakens the cross-shore, near-surface thermal gradient necessary for sea-breeze initiation, partially suppressing sea-breeze front development. Similar results are reported in Sikora et al.'s (2010) analysis of the Chesapeake Bay sea breeze on the western shore of the Delmarva Peninsula, indicating that weaker zonal flow supports the development of the circulation. Other studies (Arritt 1993; Porson et al. 2007) demonstrated that strong offshore flow $\left(>6-11 \mathrm{~m} \mathrm{~s}^{-1}\right)$ also can prevent the development of the sea breeze. The synoptic winds across Delaware often change throughout the day (Hughes and Veron 2015), which can provide opportunities for conditions favorable for sea-breeze development at multiple times during the day. The sea-breeze circulation is also influenced by the Coriolis force. In particular, at higher latitudes, the Coriolis force limits sea-breeze frontal movement inland such that maximum observed sea-breeze movement is $200 \mathrm{~km}$ inland from the coast in Australia (Simpson 1994) while only $15 \mathrm{~km}$ in Alaska (Kozo 1982). Sea breezes in southern Delaware, located at a latitude of $38^{\circ}-39^{\circ} \mathrm{N}$, are moderately affected by the Coriolis force.

The passage of a sea-breeze front causes numerous impacts on the local environment. Not only does the passage of the sea-breeze front reduce the lower-level air temperature by several degrees $\left({ }^{\circ} \mathrm{C}\right)$ within minutes, it also increases the relative humidity. This change in the meteorological properties may in turn influence the local population in their outdoor activities, as well as their indoor energy demands, by changing the heat index or thermal comfort of those on the coast (Srebric et al. 2015; Coccolo et al. 2016). In addition, pollutants can be transported inland by the circulation and then trapped by the top of the marine air mass, which acts as a dynamic cap. This prevents pollutants from escaping into the upper atmosphere because of a reduction in the mixing depth (Abbs and Physick 1992; Barbato 1975), which can degrade local air quality (Stauffer et al. 2015). The low-level atmospheric convergence of the seabreeze front with the land-based air mass can also influence convection, cloud development, and related precipitation (Atkins and Wakimoto 1997; Gahmberg et al. 2010). Finally, as sea-breeze circulations expand both landward and seaward, they may increase diurnal variability in wind speed and direction over areas proposed for offshore wind development (Mazon et al. 2015; Arritt 1989; Fett and Tag 1984).

Mesoscale meteorological models offer a platform to study the complex dynamics of sea breezes. For example, the Weather Research and Forecasting (WRF) Model (Skamarock and Klemp 2008) has been used extensively to study various characteristics of the sea breeze. In comparison with other mesoscale models, WRF outperformed the Air Pollution Model in the accuracy of surface variables such as temperature and moisture when compared to six meteorological stations in a study in Auckland, New Zealand (Khan 2010). Several studies indicate that WRF tends to overestimate the mean 10-m wind speeds by up to a few meters per second (e.g., Khan 2010; Hughes and Veron 2015; Veron et al. 2018). Studies have also shown that WRF successfully 
TABLE 1. List of meteorological stations with distance to ocean and bay coastlines.

\begin{tabular}{clccc}
\hline \hline Station & \multicolumn{1}{c}{ Location } & Start year & Distance to ocean $(\mathrm{km})$ & Distance to bay $(\mathrm{km})$ \\
\hline C1 & Rehoboth Beach & 2008 & $<1$ & 8 \\
C2 & Indian River Inlet & 2008 & $<1$ & 17 \\
C3 & Bethany Beach & 2005 & $<1$ & 28 \\
S3 & Bethany Beach & 2005 & 1 & 26 \\
S2 & Lewes & 2005 & 5 & $<1$ \\
I5 & Selbyville & 2008 & 15 & 36 \\
I2 & Harbeson & 2005 & 16 & 14 \\
I3 & Stockley & 2008 & 31 & 22 \\
I1 & Ellendale & 2008 & 32 & 17 \\
I4 & Jones Crossroads & 2005 & 43 & 31 \\
S1 & Kitts Hummock & 2005 & 44 & 3 \\
F2 & Bridgeville & 2006 & 45 & 33 \\
F1 & Harrington & 2006 & 47 & 23 \\
R1 & Laurel & 2005 & & 47 \\
\hline
\end{tabular}

simulated basic characteristics of a sea-breeze circulation such as its development, thermal intensity, and movement (Chen et al. 2011; Khan 2010). WRF has also been used to investigate sea-breeze features that are challenging to study with station observations such as return flow (Chen et al. 2011), vertical wind shear (Papanastasiou et al. 2010), and convection ahead of and above the sea-breeze front (Fovell 2005).

Until recently, the Delaware sea breeze has not been studied in detail with either observations or model data. We have developed the first detailed climatology of the Delaware sea breeze using subhourly meteorological data from 13 stations across southern Delaware (Table 1). These characteristics are then compared with model-simulated sea breezes, with focus placed on the frequency and timing of the sea-breeze front. WRF is used at a relatively high horizontal resolution of $2 \mathrm{~km}$, with 7 layers within the bottom $1 \mathrm{~km}$. At this resolution, land surface properties and local geography play an important role in WRF's abilities to simulate mesoscale features such as the sea breeze. The frontal speed and spatial characteristics of several individual fronts are also investigated. These features are important to coastal communities because slight differences in the location of a sea-breeze front can lead to significant differences in the atmospheric conditions at local scales. This work adds to the growing literature characterizing coastal wind variability in the Mid-Atlantic Bight.

\section{Methods and materials}

\section{a. Observational data}

Publically available meteorological data from 2005 to 2013 were analyzed from 13 stations operated by the Delaware Environmental Observing System (DEOS; www.deos.udel.edu), and 1 station owned by National
Data Buoy Center (NDBC; www.ndbc.noaa.gov) in Lewes, just inside the Delaware Bay. The locations of the stations are shown in Fig. 1 and details about station location and length of time series are given in Table 1. Air temperature, relative humidity, wind speed, and wind direction are observed at each station and recorded with a resolution of $5 \mathrm{~min}$ for DEOS stations and $6 \mathrm{~min}$ for the NDBC station. The stations were chosen for this analysis because of their location on the Delmarva Peninsula and relatively long time series available. Care was taken to select both coastal and inland stations. Before 2005, there are not enough stations in southern Delaware to address the spatial extent and variability of the sea breeze. Station anemometer heights are primarily $3 \mathrm{~m}$ above ground level but range up to $10 \mathrm{~m}$. When compared with model data, observed wind speeds were adjusted to $10 \mathrm{~m}$ using the $\log$ wind profile and surface roughness values that are representative of the underlying land surface, following Hughes and Veron (2015). This conversion assumes neutral atmospheric conditions.

For this project, each station is classified relative to the distance from the Atlantic Ocean as follows: $\mathrm{C} 1-\mathrm{C} 3$ are coastal $(<1 \mathrm{~km}), \mathrm{S} 1-\mathrm{S} 3$ are semicoastal $(1-5 \mathrm{~km})$, I1-I5 are inland $(6-35 \mathrm{~km})$, and F1-F2 are far inland $(36-50 \mathrm{~km})$. The stations in each class are ordered numerically by their latitudinal position in ascending order from north to south (Table 1, Fig. 1). The classification of $\mathrm{S} 1$ as a semicoastal station, even though it is located $43 \mathrm{~km}$ from the Atlantic Ocean, is an exception to this scheme. The classification of S1 was modified because of the station's close proximity to the Delaware Bay $(3 \mathrm{~km})$ and the frequent presence of sea-breeze characteristics similar to those seen at an ocean semicoastal station. Laurel, Delaware, is used as a reference station (R1) because it is located farthest from either coastline 
$(47 \mathrm{~km})$. Data from R1 are used to identify synoptically driven winds, along with corresponding temperatures, which, because of its location, will experience the sea breeze later in the day, if at all, compared to stations that are closer to the coast.

\section{b. Sea-breeze simulation with WRF}

The Delaware sea breeze, like many other coastal breezes globally, demonstrates complex development and evolution that is sensitive to spatial variability in surface temperature and roughness (Gilliam et al. 2004). To explore the spatial variability of the Delaware seabreeze frontal development in more detail, we simulate the summertime sea breeze over the Delmarva Peninsula using the WRF Model, version 3.1, for 10 summers (2000-09). The model runs focus on June, July, and August as this is when there is greatest sea-breeze frequency. The WRF atmospheric model is a state-ofthe-art mesoscale model that can be used in numerical weather forecasting and research modes (Skamarock and Klemp 2008). The WRF Model uses fully compressible and nonhydrostatic equations, employing terrain-following vertical coordinates. Monthlong simulations of the summertime sea breeze along the Delaware coastline are performed with a 24-h spinup following Hughes and Veron (2015). The WRF simulations are run on 3 nested grids with resolutions of 18-, 6-, and 2-km employing two-way nesting (Table 2). There are $100 \times$ 100 data points in the innermost domain, which covers all of southern Delaware and most of the Delaware Bay. Initial and lateral conditions are provided from NCEP-NCAR reanalysis data, with a resolution of $40 \mathrm{~km}$ and $3 \mathrm{~h}$ (Rife et al. 2004; Kalnay et al. 1996). The NCEP reanalysis data are provided by the NOAA/ OAR/ESRL Physical Sciences Division (http://www. esrl.noaa.gov/psd/; accessed October 2013).

The suite of model parameterizations employed in the current study is similar to those selected by Hughes and Veron (2015) to look at the annual cycle of low-level winds in and around the Delaware Bay and is shown in Table 2. The Noah land surface model (LSM; Chen and Dudhia 2001) was used to account for the dynamic interaction of the land surface with the atmosphere (heat flux, skin temperature, etc.). WRF run with the Noah LSM has been shown to perform well at simulating the urban heat island (Giannaros et al. 2013), which may play a role in the development of the sea breeze along the Delaware coastline. The planetary boundary layer (PBL) was parameterized with the Yonsei University scheme (Hong et al. 2006) for calculating the vertical diffusion; this parameterization has been shown to minimize observed temperature and moisture biases for 36-h simulations in comparison to simulations employing the
TABLE 2. List of WRF Model details.

\begin{tabular}{ll}
\hline \hline Version & \multicolumn{1}{c}{3.1} \\
Time frame & 2000-09 (summer) \\
Region of interest & Delmarva Peninsula \\
Domain & \multicolumn{1}{c}{3} \\
Domain resolution & $18,6,2 \mathrm{~km}$ \\
Forcing data & NCEP reanalysis \\
LSM & Noah $(40 \mathrm{~km}$ ) \\
PBL scheme & Yonsei University \\
Cumulus parameterization & Kain and Fritsch \\
Shortwave radiation & Dudhia \\
Longwave radiation & Rapid Radiative Transfer \\
& Model \\
\hline
\end{tabular}

MYJ scheme (Hu et al. 2010). The Kain and Fritsch (1993) parameterization for cumulus clouds was only employed in the largest two domains since the resolution of the innermost domain was too fine for a cumulus parameterization to be properly applied. The short- and longwave radiation was represented by the Dudhia (1989) and Rapid Radiative Transfer parameterizations (Mlawer et al. 1997), respectively.

\section{c. Sea-breeze detection scheme using observations}

Numerous studies from the past 40 years explore the best way to detect the occurrence of sea or lake breezes (Laird et al. 2001 and references therein) using station data from at least two stations (Ryznar and Touma 1981; Borne et al. 1998; Laird et al. 2001; Papanastasiou and Melas 2009). Most studies confine their analysis to daytime hours when sea and lake breezes are most active. These detection schemes are typically based on a change in wind direction from offshore to onshore flow, often employing a threshold of a $30^{\circ}$ shift in wind direction in $1 \mathrm{~h}$ (Arrillaga et al. 2016). In addition, a positive difference in temperature of at least $3^{\circ} \mathrm{C}$ between an inland station and a near-coastal station is frequently used (e.g., Borne et al. 1998; Arrillaga et al. 2016). Criteria such as a maximum wind speed threshold (Laird et al. 2001), the offshore wind direction at $850 \mathrm{hPa}$ (Papanastasiou and Melas 2009), or temperature conditions such as a cooler morning than afternoon can be used to remove synoptic events that may be confounded with a sea breeze (Laird et al. 2001). One thing to note is that though there are similarities among certain detection criteria employed in these studies, others have been somewhat tailored to fit the specifics of the sea breeze in that location because of the highly local nature of the sea breeze.

To create this new Delaware sea-breeze climatology, we developed an objective observational sea-breeze detection algorithm to identify sea-breeze frontal passage at a given location using measurements of wind 
TABLE 3. Sea-breeze detection algorithm criteria applied to the observational stations.

\begin{tabular}{|c|c|c|c|c|c|c|c|c|}
\hline & Direction & $\begin{array}{l}\text { Direction } \\
(1 \mathrm{~h} \text { ago })\end{array}$ & $\begin{array}{l}\text { Synoptic }^{a} \\
\text { direction }\end{array}$ & $\begin{array}{c}1 \mathrm{~h} \Delta \\
\text { direction }\end{array}$ & $\begin{array}{c}\text { Direction } \\
\text { gradient }\end{array}$ & $\begin{array}{l}\text { Wind } \\
\text { speed }\end{array}$ & $\begin{array}{l}1 \mathrm{~h} \Delta \\
\text { temp }\end{array}$ & $\begin{array}{c}3 \mathrm{~h} \\
\text { precipitation }\end{array}$ \\
\hline $\begin{array}{c}\text { Classic sea } \\
\text { breeze }\end{array}$ & Onshore & Offshore/calm & Offshore/calm & $>45^{\circ}$ & - & $>1.0 \mathrm{~m} \mathrm{~s}^{-1}$ & $<-2.0^{\circ} \mathrm{C}$ & $<0.1 \mathrm{~mm}$ \\
\hline $\begin{array}{l}\text { Weak sea } \\
\text { breeze }^{\text {b }}\end{array}$ & Onshore & Onshore & Offshore/calm & - & $>45^{\circ}$ & $>1.0 \mathrm{~m} \mathrm{~s}^{-1}$ & - & $<0.1 \mathrm{~mm}$ \\
\hline
\end{tabular}

${ }^{\text {a }}$ Synoptic conditions approximated by a station location in Laurel, Delaware (R1).

${ }^{\mathrm{b}}$ Onshore conditions for $1 \mathrm{~h}$ consecutively. Predominantly offshore synoptic flow during the last hour (75\%).

speed, wind direction, temperature, and precipitation from a nearby meteorological station (called a sample station in this analysis). The objective algorithm detected hourly changes in meteorological conditions using a sliding window that shifted at 5-min intervals from 1200 to 0000 UTC (0800-2000 local time during the summer season). For example, at 0800 the algorithm compared the observations from 0800 to those taken at 0700 . Then the code is incremented to 0805 and compared to the observations from 0705 . A 1 -h window was chosen because it is a reasonable amount of time to expect differences due to a sea breeze. A larger window would most likely have other, larger-scale processes influencing the detection code. Once a sea-breeze front was detected, then changes in these physical characteristics before and after frontal passage at the sample station were compared to the reference station (R1), which was typically unaffected by the front and thereby used to represent the large-scale, near-surface conditions. If more than $25 \%$ of either the wind or temperature data were missing at either the sample meteorological station or reference inland station for the day, then the entire day was removed from the sample station's dataset. Therefore, the number of detected sea breezes varies at each station in part because of data availability.

Preliminary analysis of the data showed that there are two distinct types of sea breezes, a classic sea breeze and a weak sea breeze, which occur on the Delaware coast. Therefore, two sets of detection criteria were developed based on the magnitude and quickness of changing meteorological conditions at each station relative to the reference station (Table 3). The criteria employed for each category were adapted from previous studies (Ryznar and Touma 1981; Borne et al. 1998; Laird et al. 2001; Papanastasiou and Melas 2009) to enable objective detection of Delaware sea breezes that are relatively weak compared to sea breezes in other locations, like Florida. There are four detection criteria that are common between the two techniques. For example, both detection categories require the wind at the sample station to have onshore flow with a wind speed greater than $1 \mathrm{~m} \mathrm{~s}^{-1}$, which is near the detectable limit for most operational anemometers. In addition, both classifications also require that the reference station has offshore (westerly) flow or calm winds at the same time to prevent false identification of a sea breeze due to an onshore synoptic flow. Dry conditions $(<0.1 \mathrm{~mm})$ for $3 \mathrm{~h}$ prior to frontal passage are required to prevent false detection of seabreeze-like conditions caused by a precipitation-induced drop in temperature and shift in wind direction.

The two classifications differ in the other four detection criteria, most notably in the temperature and wind direction criteria. The classic sea breeze category is defined by a rapid direction change $\left(>45^{\circ}\right)$ from offshore to onshore (westerly to easterly) winds with at least a $2^{\circ} \mathrm{C}$ drop in temperature over an hour (Table 3 ). The thermal threshold of $2^{\circ} \mathrm{C}$ is chosen because it is large enough to filter out the difference between temperature drops associated with changes in solar radiation and those associated with sea breeze. The temperature threshold is lower than in previous studies (e.g., Borne et al. 1998; Arrillaga et al. 2016) because the Delaware sea breeze moves inland slowly, often causing the marine air mass to heat significantly as it travels over land. Therefore, there are not as large changes in temperature pre- and post-sea-breeze frontal passage. Note that, although the detection criteria search for changes in meteorological properties over a 1-h window, frequently these sea-breeze-induced changes in temperature and wind occurred within $15 \mathrm{~min}$ or less. This is interesting because it allows for relatively precise identification of the frontal passage time. The direction criteria also prevent smallscale wind variation, such as switching from $5^{\circ}$ offshore to $5^{\circ}$ onshore, from falsely signaling a sea breeze.

The weak sea breeze category accounts for an observed wind direction gradient that can develop between a sample station and the reference station without the algorithm recognizing the moment of frontal passage at the sample station. This occurs primarily if the sea-breeze front develops landward of the sample station or moves very slowly over the coastal region. To ascertain that a sea-breeze front did indeed occur, this classification requires $1 \mathrm{~h}$ of $100 \%$ persistent winds $(\sim 12$ consecutive values) from the east at a sample station and $75 \%$ persistent calm or westerly flow at the reference 
Sea Breeze Frequency

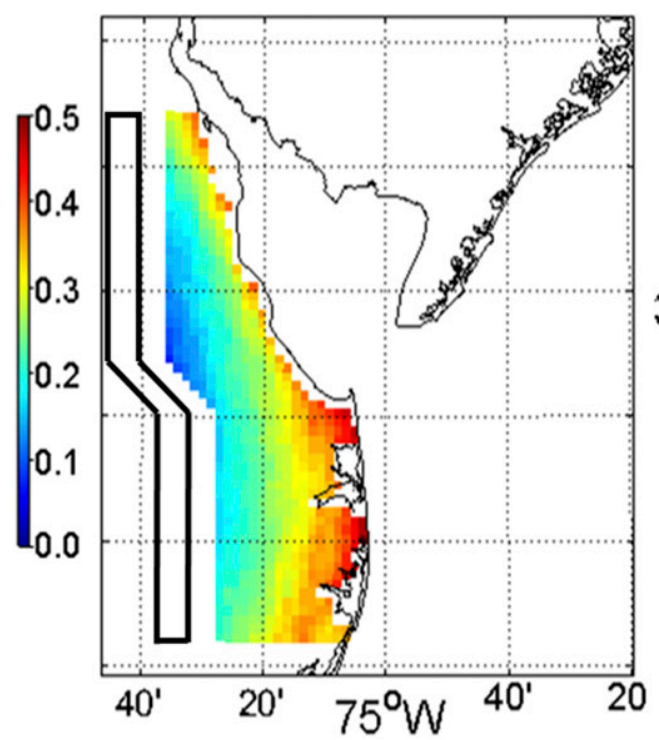

Time of Arrival

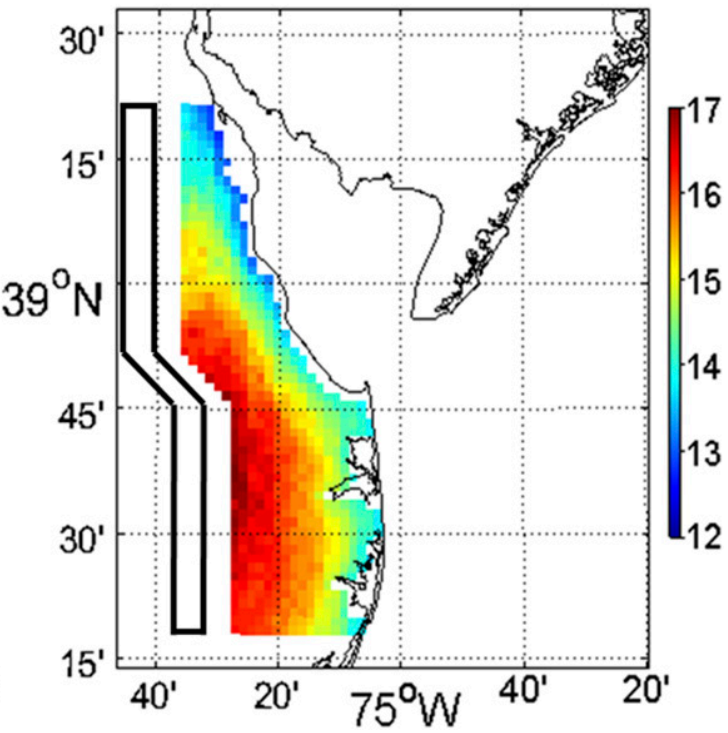

FIG. 2. WRF-simulated sea-breeze frequency and mean time of arrival (UTC) for the summers of 2000-09. The black bordered polygon encompasses the cells that make up the reference region. The colored pixels show the sample region. The true coastline is overlaid onto the modeled grid cells.

station. Less persistence is required at the reference station because of the increased wind variability associated with lighter, synoptically driven wind speeds. In addition, the concurrent difference in wind direction between a sample station and the reference station needs to be greater than $45^{\circ}$. These additional criteria eliminate cases where the wind direction gradient is driven by small-scale changes in the synoptic winds, or a localized rainfall event. The seabreeze detection criteria are applied to all 13 sample stations in the observational dataset (Fig. 1, Table 1).

If either category of sea breeze was not detected at a sample station on a given day, then the day was categorized as either onshore dominant, offshore dominant, or variable depending on the prevailing winds observed at that particular station. In relation to the Delaware's Atlantic-facing coastline, onshore flow is considered to be from the east and offshore flow is considered to be from the west. The Delaware Bay-facing coastline is oriented slightly differently (north-northwest-south-southeast), but the same direction criteria can be applied as the case of a sea breeze developing over the Delaware Bay with a flow from the west is extremely rare. These Delaware Bay breeze cases still end up being detected by the algorithm as sea breezes, albeit a bit late, as the wind shifts to be more easterly.

\section{d. Sea-breeze detection scheme using model data}

A model sea-breeze detection algorithm was also developed using the 10 summers (June, July, and August) of
WRF output to develop a model sea-breeze climatology and compare the characteristics of the modeled Delaware sea breeze to the observed ones. Model data provide the opportunity to explore the presence of a front over a large region at a higher spatial resolution $(2 \mathrm{~km})$ than in the observational data. The model data also supply detailed information on the shape of the front as well as how the wind direction shifts in response to frontal passage.

The objective detection algorithm for the model is more simplistic than the one created for observations in part because only hourly data were saved because of the long duration of the model runs. In addition, the modeled sea breeze is weaker than that observed and so more challenging to detect. In particular, there are no temperature criteria applied to the model data, similar to the method employed for the weak observed seabreeze detection. Also, in lieu of a single reference station or grid cell, a larger reference region is used that includes over 100 grid cells across the middle of the Delmarva Peninsula. For each hour, a mean wind component is computed for the reference region. Land grid cells to the east of the reference region compose the sample region where sea-breeze frequency and time of arrival statistics are compiled for each grid cell. Figure 2 depicts both the modeled sample and reference regions along with sea-breeze frequency and arrival time results from the model. In order for a sea breeze to be detected in the model data, the following conditions based on the magnitude of the $u$-wind (east/west) component at $10 \mathrm{~m}$ 
TABLE 4. Classification of typical observed summertime wind events (2005-13). Non-sea-breeze events are classified based on the prevailing daytime wind direction.

\begin{tabular}{|c|c|c|c|c|c|c|c|c|}
\hline Station & $\begin{array}{l}\text { Distance from } \\
\text { coast }(\mathrm{km})\end{array}$ & $\begin{array}{c}\text { Total sea } \\
\text { breeze (\%) }\end{array}$ & $\begin{array}{l}\text { Classic sea } \\
\text { breeze (\%) }\end{array}$ & $\begin{array}{c}\text { Weak sea } \\
\text { breeze (\%) }\end{array}$ & $\begin{array}{l}\text { Offshore } \\
\text { wind (\%) }\end{array}$ & $\begin{array}{l}\text { Onshore } \\
\text { wind (\%) }\end{array}$ & $\begin{array}{l}\text { Variable } \\
\text { wind }(\%)\end{array}$ & $\begin{array}{l}\text { Sample } \\
\text { size }\end{array}$ \\
\hline $\mathrm{C} 2$ & $<1$ & 69 & 32 & 37 & 10 & 16 & 5 & 523 \\
\hline $\mathrm{C} 1$ & $<1$ & 68 & 38 & 30 & 9 & 19 & 4 & 513 \\
\hline $\mathrm{C} 3$ & $<1$ & 67 & 37 & 30 & 7 & 22 & 4 & 792 \\
\hline $\mathrm{S} 2$ & $<1$ & 56 & 13 & 43 & 13 & 11 & 19 & 678 \\
\hline S3 & 1 & 52 & 14 & 38 & 18 & 21 & 8 & 811 \\
\hline S1 & 3 & 34 & 8 & 26 & 36 & 19 & 12 & 749 \\
\hline $\mathrm{I} 2$ & 14 & 36 & 11 & 25 & 33 & 17 & 13 & 752 \\
\hline I5 & 15 & 11 & 6 & 5 & 43 & 14 & 31 & 550 \\
\hline I1 & 17 & 15 & 7 & 8 & 43 & 17 & 25 & 550 \\
\hline $\mathrm{I} 3$ & 22 & 33 & 17 & 16 & 33 & 20 & 14 & 552 \\
\hline $\mathrm{F} 1$ & 23 & 14 & 8 & 6 & 50 & 17 & 19 & 712 \\
\hline $\mathrm{I} 4$ & 31 & 22 & 13 & 9 & 38 & 22 & 18 & 747 \\
\hline $\mathrm{F} 2$ & 33 & 13 & 8 & 5 & 49 & 19 & 18 & 732 \\
\hline
\end{tabular}

are applied: 1) the reference region wind has a westerly flow (offshore) or is calm $\left.\left(<1 \mathrm{~m} \mathrm{~s}^{-1}\right), 2\right)$ the sample cell wind has an easterly flow, 3 ) the sample cell wind from $1 \mathrm{~h}$ prior had a westerly flow or was calm, and 4) the easterly wind component is at least $2 \mathrm{~m} \mathrm{~s}^{-1}$ greater at the sample cell compared to the reference region. The model sea-breeze detection algorithm evaluates these conditions at every sample cell (grid cell in the sample region) for each hour between 1200 and 0000 UTC, which corresponds to daylight hours.

\section{e. Deriving sea-breeze characteristics}

Once the occurrence of a sea breeze has been detected in either the observational or model data, then that day is classified a sea-breeze day. The sea-breeze occurrence was then analyzed diurnally, seasonally, and interannually. To look at the diurnal variability, we calculated the mean meteorological values and create a composite of sea-breeze days by aligning each day $($ time $=0$ ) based on the arrival time of the sea-breeze front for four DEOS stations. Once the composite time series were produced, then the wind speed, temperature, and dewpoints were analyzed for a period that runs from $4 \mathrm{~h}$ before and to $4 \mathrm{~h}$ after the passage of the front. This method provides insight into how sea-breeze persistence, along with temperature, humidity, and wind speed changes associated with the sea-breeze frontal passage, varies with distance from the coast.

Seasonal and diurnal variations were also studied by assessing the evolution of temperature and relative humidity for classic sea-breeze days. Interannual variability of sea-breeze occurrence was also calculated. To investigate the sea-breeze frontal speed, the analysis focused on three stations with varying distances from the Atlantic coastline (C3, S3, and I3). When a classic sea breeze moved through two of the stations, then the difference in frontal arrival time was used to calculate the frontal speed between those two stations. In addition, for all sea-breeze days, characteristics such as occurrence, onset time, inland penetration, and duration were also calculated from both model and observed data and then compared.

\section{Results}

\section{a. Observed sea-breeze frequency}

Analysis of the meteorological station data showed that a Delaware sea breeze (either "classic" or "weak") occurs in at least one station $70 \%-80 \%$ of the days during the daylight hours (1200-0000 UTC) in the summer months (June, July, and August) for the entire study period (Table 4). In comparison to other studies, this number is higher than the percentage of sea breezes detected in two cities along the coastline in northern Spain (48\% for June and July; Arrillaga et al. 2016) and Sweden (17\%-38\% for May to September; Borne et al. 1998). Some of this variation in sea-breeze frequency is due to differences in the geographic location and periods of the studies, and some may be due to how far inland the sea breeze was detected. For example, in this study, the analysis demonstrated that the summertime frequency of the sea breeze varied with distance from the coastline (Table 4), an effect also noted by Bigot and Planchon (2003) on the northern coast of France.

The sea-breeze circulation was detected at stations within $1 \mathrm{~km}$ of the coastline $(\mathrm{C} 1-\mathrm{C} 3)$ approximately $70 \%$ of the time, whereas at $\mathrm{S} 3$, located $1 \mathrm{~km}$ inland of $\mathrm{C} 3$ (or $2 \mathrm{~km}$ from the coast), the sea-breeze frequency decreased to $52 \%$. This indicates that approximately $28 \%$ of the time the sea-breeze front moved inland past 
the coastline $(\mathrm{C} 3)$ but it did not reach farther than $1 \mathrm{~km}$ inland (S3). There are several possible reasons for this; the sea-breeze front may have stagnated along the coast because of opposing winds from synoptic systems (Porson et al. 2007), or it may have passed through the inland station but was not detected by the algorithm. This happens for slow moving sea-breeze fronts that warm as they move over the land surface, and so fail the temperature criteria of the detection algorithm. Stations located more than $20 \mathrm{~km}$ from the coastline are impacted by sea-breeze conditions only $15 \%$ of the time during the summer.

We examined the seasonality of sea-breeze frequency along Delaware's coastline by looking at pairs of stations in each region (Fig. 3). The highest sea-breeze frequency occurred in the summer (approximately $10 \%-70 \%$ ) and was lowest during the winter (approximately $5 \%-25 \%$ ) for all regions (coastal, semicoastal, inland, and far inland). The coastal region, characterized by Atlantic-facing stations within $1 \mathrm{~km}$ of the coast (C1$\mathrm{C} 3$ ), showed the closest agreement among stations in detected sea-breeze occurrence throughout the year with differences typically $<5 \%$. For the other regions, the greatest variability among stations occurred in the spring and fall transition seasons, and may be related to seasonal changes in dominant wind patterns as well as variations in sea surface temperature.

Some of the seasonal variation in sea-breeze frequency can be related to seasonal changes in surface temperatures for both land and sea. Analysis of the meteorological station data over the entire period from 2005 to 2013 showed that the Delaware coast, which is located in the Mid-Atlantic Bight, experienced a strong seasonal cycle in mean surface air temperatures from $3^{\circ}$ to $30^{\circ} \mathrm{C}$ (not shown). The length of daylight ranged from $10 \mathrm{~h}$ in the winter to $14 \mathrm{~h}$ in the summer and contributed to this variability in temperature. Ocean sea surface temperatures also vary seasonally over a much smaller range along the Atlantic Coast; however, in the summer the Delaware Bay sea surface temperatures can range from below $20^{\circ} \mathrm{C}$ to over $25^{\circ} \mathrm{C}$ with significant spatial and temporal variability, driven in part by variations in local winds (Voynova et al. 2013).

There is considerable spatial and temporal variability in the frequency of sea-breeze days across the region. In all months the sea-breeze frequency drops with distance from the coast; however, there is a difference in sea breezes that initiate from the ocean coastline and those that initiate from the bay coastline. For example, S1, located close to the Delaware Bay coastline has a lower sea-breeze frequency than Atlantic-facing stations within $1 \mathrm{~km}$ of the coastline such as $\mathrm{C} 1-\mathrm{C} 3$ (Table 4). Although S1 is near the Delaware Bay coast, it is over

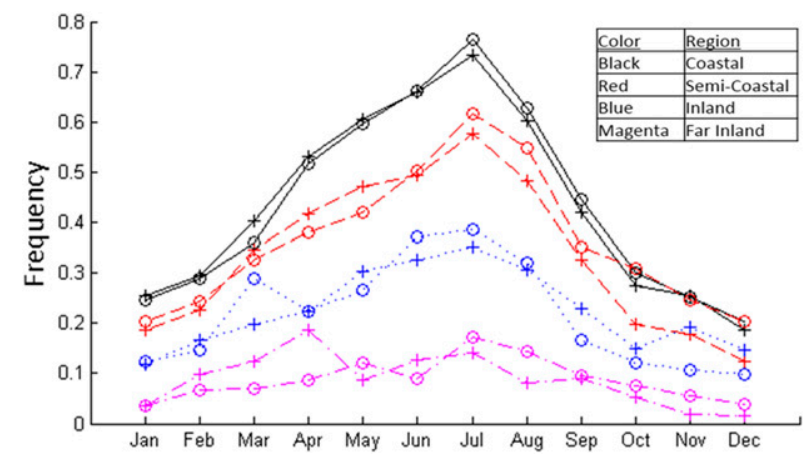

FIG. 3. Observed sea-breeze frequency by month and location. Each region is defined by its distance from the Atlantic coastline. The coastal stations are $\mathrm{C} 3$ and $\mathrm{C} 2(<1 \mathrm{~km}), \mathrm{S} 3$ and S2 are semicoastal $(1-3 \mathrm{~km})$, the inland stations are I3 and I $2(3-25 \mathrm{~km})$, and the far inland stations are F2 and F1 (25-50 km). For each region (color), the first station is represented by the line with the plus signs and the second station is represented by the line with the open circles.

$40 \mathrm{~km}$ from the Atlantic Ocean, yet the sea-breeze frequency is much greater at $\mathrm{S} 1$ than at other stations that are at a similar distance from the Atlantic Ocean (S1: $34 \%, \mathrm{~F} 1: 14 \%$, and $\mathrm{F} 2: 13 \%$ ) but farther from the bay. This demonstrates that the sea breeze originating over the Delaware Bay had a detectable impact on the region but that the sea breeze originating from the bay coastline may occur less frequently or with less strength than those originating from the ocean coast.

The frequency of sea breezes occurring at any given station also demonstrates some interannual variability as summarized in Table 5 for $\mathrm{C} 3$, a coastal station with a relatively long period of record (2005-13). At this station, the total (classic) sea breeze was detected on $57 \%-$ $80 \%(27 \%-47 \%)$ of days in a given summer, depending on the year. This variability is typical of what is seen throughout the region.

\section{b. Observed sea-breeze characteristics}

Sea-breeze frontal speed was assessed by looking at the timing of classic sea-breeze detection in three stations with varying distances from the Atlantic coastline (C3, S3, and I3). With the assumption that the front propagates directly perpendicular to the Atlantic-facing coastline, the calculated frontal speeds range from $0.8 \mathrm{~km} \mathrm{~h}^{-1}$ between $\mathrm{C} 3$ and $\mathrm{S} 3$ to $5.0 \mathrm{~km} \mathrm{~h}^{-1}$ between $\mathrm{C} 3$ and I3 (see Fig. 4). This suggests that the front moves very slowly within the first kilometer of the coastline and then picks up speed as it moves inland. However, it is important to note that the front may move forward and backward before reaching each of the inland stations so the calculated speed is a relative "forward speed." These results agree with prior studies indicating that sea/ lake breezes typically move between 1.5 and $7 \mathrm{~km} \mathrm{~h}^{-1}$ 
TABLE 5. Classification of observed summertime wind events at C3 showing interannual variability. Non-sea-breeze events are classified based on the prevailing daytime wind direction.

\begin{tabular}{|c|c|c|c|c|c|c|c|}
\hline Year & $\begin{array}{c}\text { Total sea } \\
\text { breeze }(\%)\end{array}$ & $\begin{array}{l}\text { Classic sea } \\
\text { breeze (\%) }\end{array}$ & $\begin{array}{c}\text { Weak sea } \\
\text { breeze (\%) }\end{array}$ & $\begin{array}{l}\text { Offshore } \\
\text { wind }(\%)\end{array}$ & $\begin{array}{c}\text { Onshore } \\
\text { wind (\%) }\end{array}$ & $\begin{array}{c}\text { Variable } \\
\text { wind }(\%)\end{array}$ & $\begin{array}{l}\text { Sample } \\
\text { size }\end{array}$ \\
\hline 2005 & 59 & 32 & 27 & 5 & 32 & 4 & 75 \\
\hline 2006 & 59 & 35 & 24 & 11 & 23 & 8 & 75 \\
\hline 2007 & 65 & 45 & 20 & 4 & 27 & 4 & 92 \\
\hline 2008 & 80 & 47 & 33 & 7 & 14 & 0 & 92 \\
\hline 2009 & 57 & 27 & 30 & 9 & 26 & 8 & 92 \\
\hline 2010 & 74 & 37 & 37 & 7 & 15 & 4 & 92 \\
\hline 2011 & 78 & 38 & 40 & 5 & 15 & 1 & 92 \\
\hline 2012 & 63 & 36 & 27 & 9 & 28 & 1 & 90 \\
\hline 2013 & 66 & 36 & 30 & 11 & 17 & 5 & 92 \\
\hline
\end{tabular}

(Physick 1980; Tijm et al. 1999; Keeler and Kristovich 2012). These results also suggest that coastal cities may contribute to a slowing of the sea-breeze front as it moves across them as noted in other studies (Bornstein and Thompson 1981; Thompson et al. 2007).

The impact of the sea breeze on the mean surface atmospheric temperature varies throughout the day (1000-0000 UTC). This is shown in Fig. 5 for a seasonal composite of classic sea-breeze days detected at C3 (Bethany Beach) compared to a composite of the same days at the reference station. For each season, the station closest to the coast (C3) was slightly warmer than the reference station during the morning hours before any sea-breeze development, possibly because of the siting characteristics of those stations or the relatively warm nearby sea surface temperatures. However, once the sea-breeze events initiate then the relative difference between the two stations inverted to show significant cooling at the coastal station at and after sea-breeze frontal passage. On average, the coastal station remained cooler than the inland station until at least sunset in all seasons (Fig. 5). The largest seasonally averaged sea-breeze-induced temperature change occurred in the spring with a statistically significant $(p<0.01)$ paired mean difference of over $5^{\circ} \mathrm{C}$ during the late afternoon. Overall, the thermal effect of the sea breeze is most prominent in the midmorning (1300 UTC, 0900 EDT) during the summer and late morning (1600 UTC, 1100 EST) during the winter, which is about $3-4 \mathrm{~h}$ after sunrise in each season. Delaware local time is UTC $-4 \mathrm{~h}$ in the summer and UTC $-5 \mathrm{~h}$ in the winter.

The passage of a sea-breeze front leads to detectable changes in meteorological conditions at every sample station. These changes are shown in Fig. 6 using data from stations $\mathrm{C} 2, \mathrm{C} 3, \mathrm{~S} 3$, and $\mathrm{I} 2$ where the conditions for all classic sea-breeze days detected by the algorithm are averaged and aligned based on the timing of frontal passage. This also emphasizes that the mean arrival time of the sea breeze is delayed with increasing distance from the coast (example shown Fig. 6a). The mean arrival time of the detected sea-breeze front increases by approximately $2 \mathrm{~h}$ (1600-1800 UTC) from C3 to S3, which are separated by a distance of $1 \mathrm{~km}$. The mean
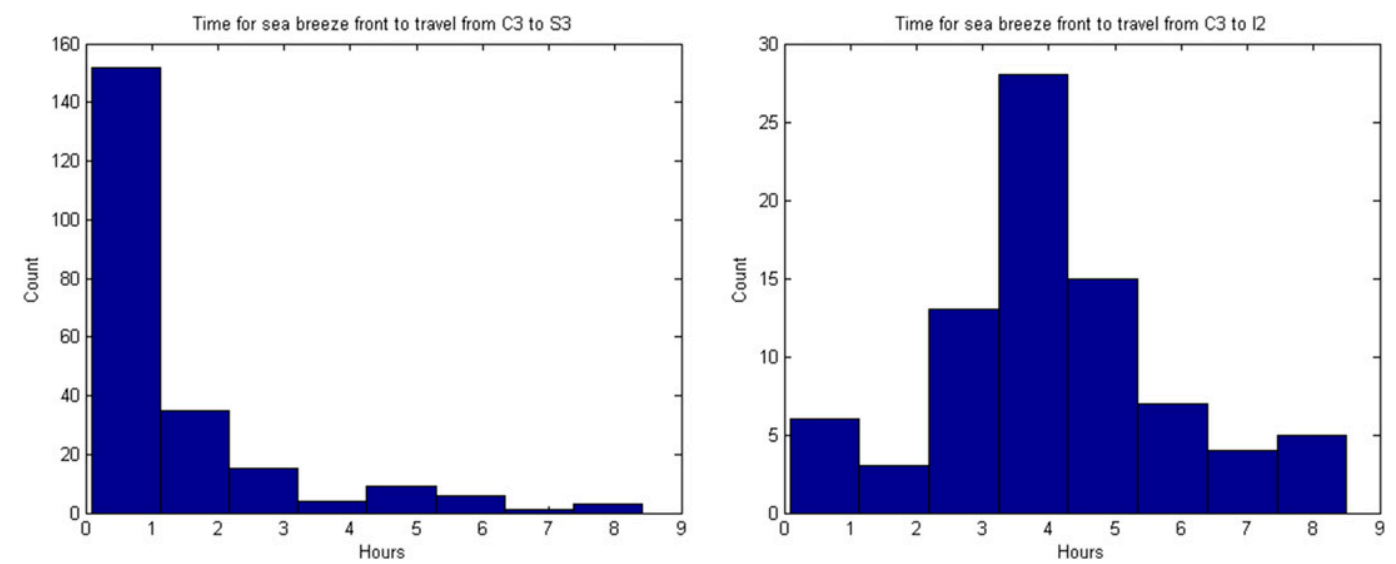

FIG. 4. Histograms showing the arrival time of a sea-breeze front initially detected at the coastal station C3 at (left) $\mathrm{S} 3,1 \mathrm{~km}$ inland from the coast, and (right) $\mathrm{I} 3,22 \mathrm{~km}$ inland from the coast. 


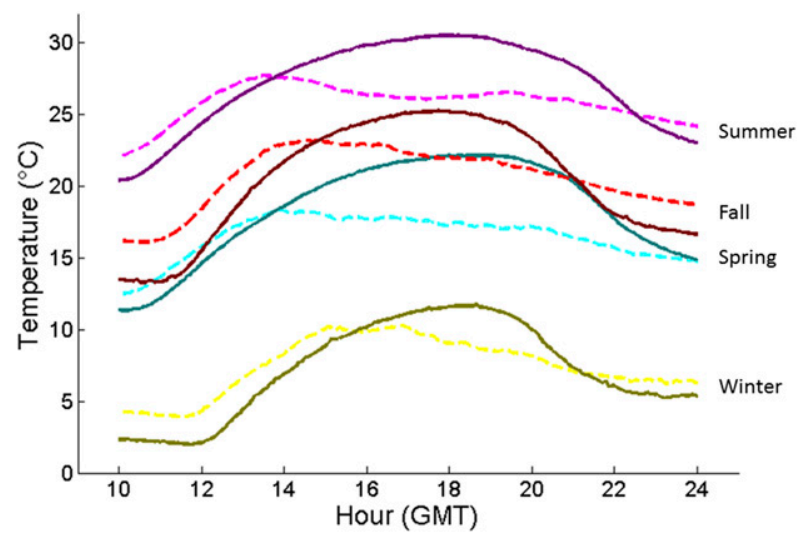

FIG. 5. Mean diurnal variation in surface air temperature at an inland station (R1; solid) and a coastal station (C3; dashed) during classic sea-breeze days, by season. The lighter of each color pair represents values from the coastal station and the darker color indicates those from the reference inland station.

arrival time at $\mathrm{I} 2$, located $15 \mathrm{~km}$ farther inland, is approximately 2100 UTC.

Differences in the mean wind speed, temperature, and dewpoint at C2 (a station near the shoreline), S3 (located $1 \mathrm{~km}$ inland), and I2 (located $16 \mathrm{~km}$ inland) illustrate the spatial variation that the sea breeze introduces as it moves through the region (Figs. 6b-d). $\mathrm{C} 3$ has the largest sample size of the coastal stations but is situated near buildings, which can impact wind speeds from the west. Therefore, $\mathrm{C} 2$ is used instead of $\mathrm{C} 3$ for the representation of meteorological conditions before and after frontal passage at the coast. On average, $3 \mathrm{~h}$ after the front moves through each location, the winds weaken at I2, remain constant at $\mathrm{S} 3$, and increase at $\mathrm{C} 2$. This suggests that the sea-breeze-induced onshore flow often increases after the front moves past the coastline, a feature not seen as the front passes through stations farther inland. At all three locations the mean temperature drops by over $3^{\circ} \mathrm{C}$ in response to the passing front. After the front passes, the mean temperature remains constant at $\mathrm{C} 2$ and $\mathrm{S} 3$ but continues to drop at I2. This is probably due to the late arrival of the front coinciding with a decrease in incoming solar radiation. The mean dewpoint increases ahead the frontal passage and then remains constant with $\mathrm{C} 2$ demonstrating the smallest increase. However, there were cases, typically on moist days, where the dewpoint drops after passage of the front. This may be due to the marine air mixing with the continental air within the convective internal boundary layer.

\section{c. Observational case studies}

The description of the average conditions before and after frontal passage does not demonstrate the complexity of the developing sea-breeze front. For example, the sea-breeze detection algorithm only detects the first instance of a sea breeze during the day; however, a more

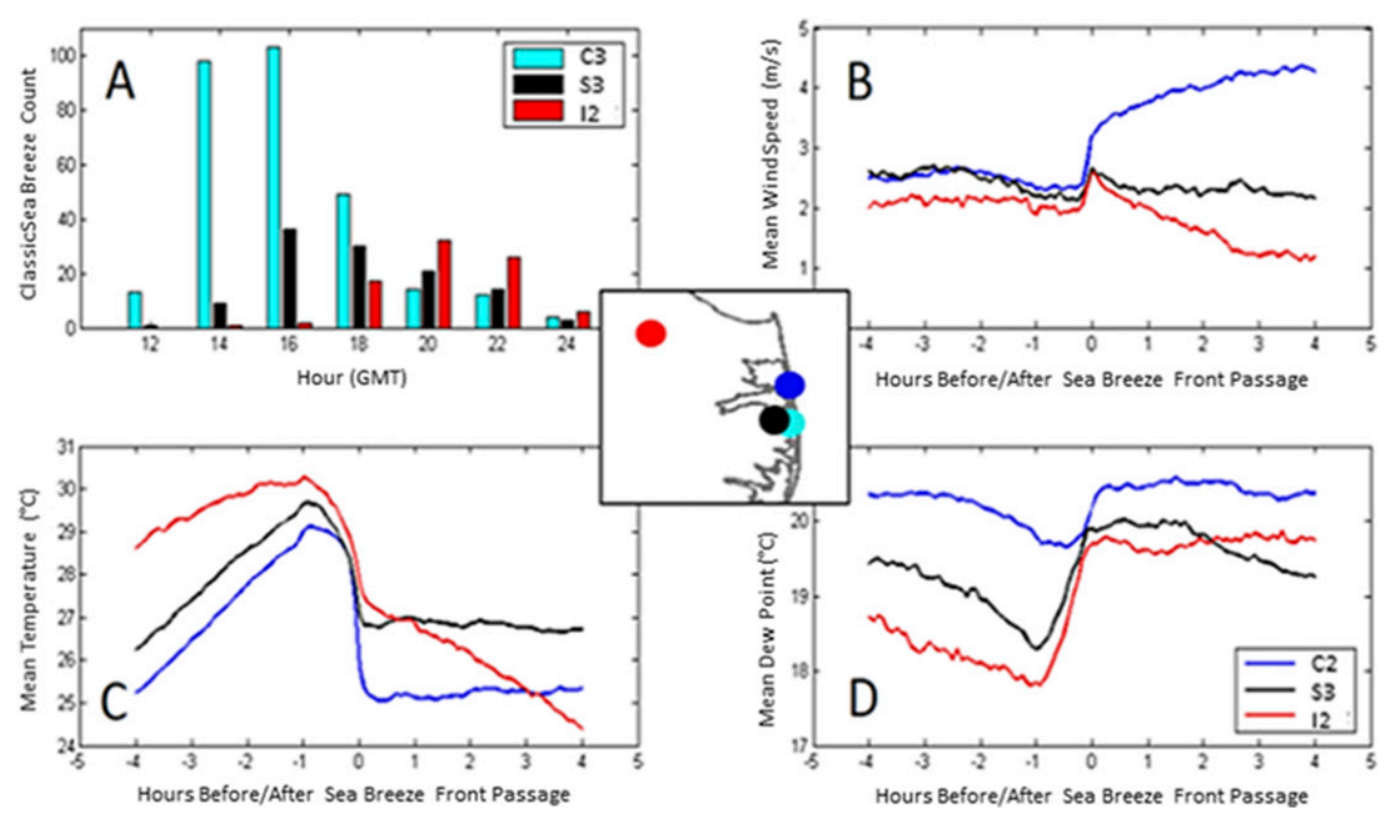

FIG. 6. Mean observed conditions before and after classic sea-breeze frontal passage. (a) Sea-breeze count binned by hour of occurrence; (b) mean wind speed; (c) mean temperature; (d) mean dewpoint. The central legend indicates the relative location of each station based on color: C2 - dark blue, C3-light blue, S3-black, and I2-red. 
July 15, 2009
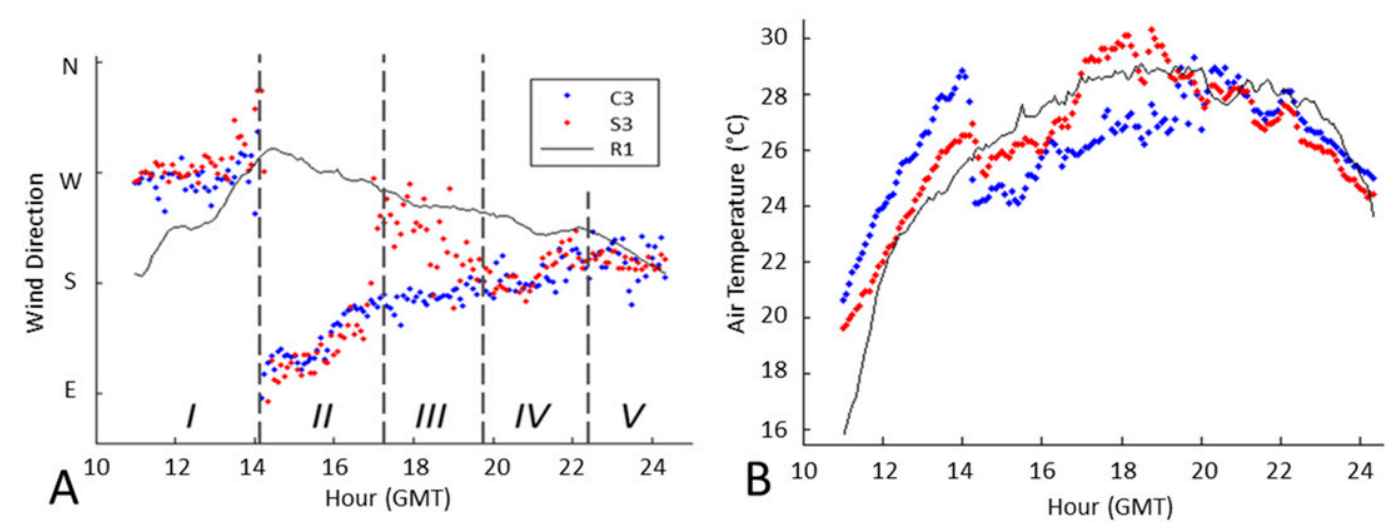

FIG. 7. Frontal movement of a sea-breeze front. The (a) wind direction and (b) air temperature time series are presented for $\mathrm{C} 3(\sim 0.1 \mathrm{~km}$ from the coast), S3 ( $\sim 1 \mathrm{~km}$ from the coast), and R1 ( $47 \mathrm{~km}$ from the coast). Wind shifts from onshore (west) to offshore (east) suggest the passage of a sea-breeze front.

intensive investigation of the meteorological data reveals that the front can move both forward (landward) and backward (seaward) so that the algorithm is missing cases when the sea breeze retreats and then advances again. Therefore, we select two interesting cases that illustrate the complex dynamics of the Delaware sea breeze such as frontal advance and retreat and the interaction of multiple distinct sea-breeze fronts that can develop and pass through a region.

The first case study shows a retrograding sea-breeze front that passed through S3 on 15 July 2009 (Fig. 7). In the morning hours, a synoptic west wind was present at all stations (stage I, Fig. 7). At 1400 UTC (1000 EDT) the sea-breeze front moved through two stations (C3, S3) as indicated by the wind shift and temperature drop (stage II). By 1700 UTC (1500 EDT) the front appeared to retrograde back across S3 station (stage III) or dissipate, and then $2 \mathrm{~h}$ later a sea-breeze front passed through again, headed inland (stage $I V$ ). The observed temperature and dewpoint (not shown) all changed in response to the onshore and offshore wind regimes, showing the frontal advance and retreat. However, C3 only experienced one sea-breeze frontal passage during this day, suggesting that the retreat of the sea-breeze front did not make it all the way back to the coast.

The second case study, 30 July 2009, shows a situation where the station S2, located near the mouth of the Delaware Bay was impacted by two separate wind shifts, each associated with a different sea-breeze front (Fig. 8) while a nearby coastal station, $\mathrm{C} 3$, only experienced one sea breeze. Early in the day, the winds are from the northwest (stage I). Around noon (1600 UTC or 1400 EDT) on this day, the winds shifted clockwise from the northwest to the northeast at S2 while at the reference station the winds changed slightly from the WNW to the west (stage II). This difference in wind direction can be explained by the development of a sea breeze from the Delaware Bay. Shortly after, C3 experienced a strong sea-breeze front that shifted winds from the west to the southeast (stage III) as a sea breeze from the ocean coastline passes over the station. Similar wind conditions progressed to $\mathrm{S} 2$ within $2 \mathrm{~h}$, causing a second, distinct wind shift from the northeast to the southeast (stage $I V)$. There was no significant change in temperature at S2 because of the slow change in the wind direction, and because the marine air has more time to heat up over the land surface before reaching the station. These stations are located on the Delmarva Peninsula, which is surrounded by the Delaware Bay, the Atlantic Ocean, and the Chesapeake Bay. When the temperature is warm and the synoptic winds are light, it is possible to have the interaction (or convergence) of up to three fronts, from each coastline, over Southern Delaware.

\section{d. Model sea-breeze occurrence}

Sea-breeze statistics are computed from WRF Model output for the summers of 2000-09 using the detection algorithm described in section 2c (Fig. 2). In general, the model underpredicts sea-breeze occurrence, especially within the first $20 \mathrm{~km}$ of the coastline. As expected, the sea-breeze frequency is highest along the Atlantic $(50 \%)$ and Delaware Bay ( $40 \%)$ coastlines similar to the observations. Analysis of the model results suggest that sea-breeze frequency drops roughly $10 \%$ every $10 \mathrm{~km}$ inland from the Atlantic Coast (Fig. 2), more slowly than what is seen in the observations (Table 1), although the data are challenging to interpret with the influence of sea breezes from multiple coastlines. However, it is important to 


\section{July 30, 2009}
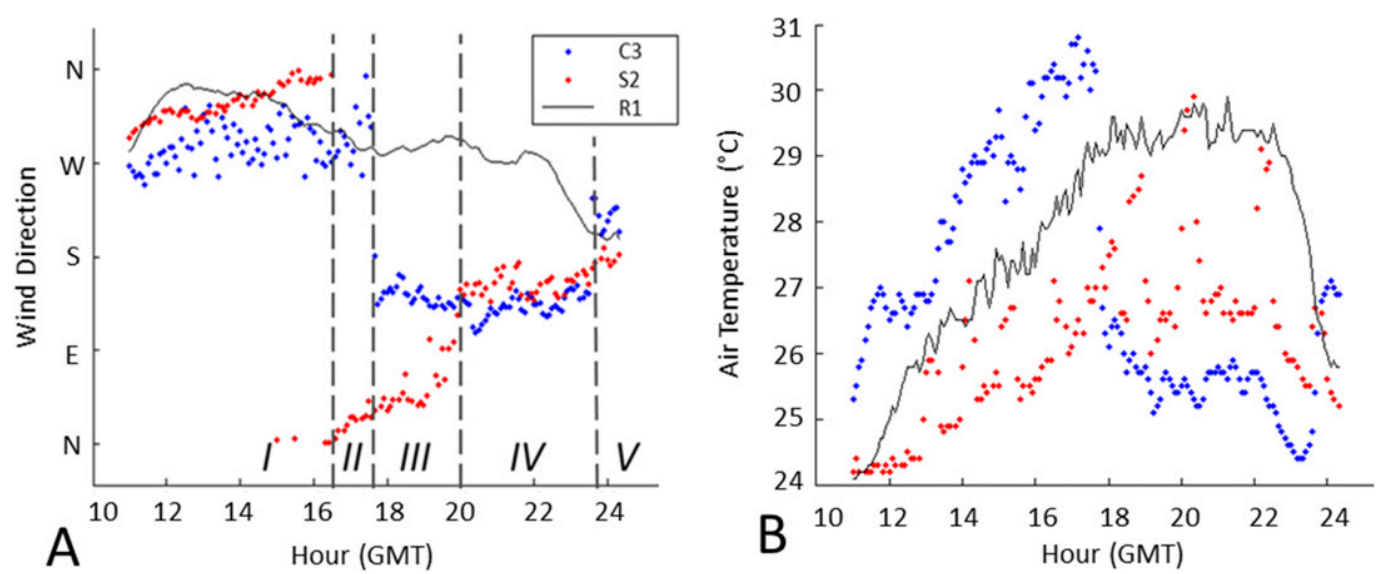

FIG. 8. Passage of two distinct sea-breeze fronts on $30 \mathrm{Jul}$ 2009. The (a) wind direction and (b) air temperature time series are presented for C3 ( $\sim 100 \mathrm{~m}$ from the coast), S2 (near the mouth of the Delaware Bay), and R1 (47 km from the coast). At S2 the wind shifts slowly (weak sea breeze) from NW to NE as the Delaware Bay-originating sea breeze passes through ( 1600 UTC). At 1700 UTC, a strong shift in the wind direction (W to SE) is observed at $\mathrm{C} 3$ with a classic sea-breeze front originating from the Atlantic Ocean. This front appears to pass through S2 around 2100 UTC with a secondary wind shift from NE to SE.

note that the greatest drop observed in sea-breeze frequency is within the first kilometer of the coastline: a feature that is impossible for the model to replicate at a horizontal resolution of $2 \mathrm{~km}$.

Interestingly, WRF appears to predict correctly the frequency of sea-breeze occurrence along the Delaware Bay coast at both S2, near where the Delaware Bay meets the Atlantic Ocean, and at S1 farther up the Delaware Bay coastline. The difference in the model skill in predicting sea-breeze frequencies originating from the ocean coastline and the bay coastline may be attributed in part to the use of climatological SSTs in this study, which are cooler than observations by buoy and satellite data suggest (M. Oliver 2013, personal communication). It also due to the model sea breeze being weaker than that observed, leading to the model missing roughly $20 \%$ of the observed sea breezes. As observed, the frequencies drop with distance from the coastline to about $20 \%$ for the region that is $30-\mathrm{km}$ inland.

\section{e. Model sea-breeze characteristics}

The arrival time of the sea breeze in the model typically occurs in the morning, first along the coast of the Delaware Bay (1300 UTC, 0900 EDT) and then along the Atlantic Coast (1400 UTC, 1000 EDT). These arrival times are slightly earlier than the observed average; however, both datasets indicate a large increase in the mean arrival time with increasing distance from the coast. This effect is most pronounced within the first several kilometers from the ocean coast. The wind direction shift in the WRF Model also agrees well with observed values, which typically shift from the west to the southeast or occasionally from the west to the northeast during sea-breeze frontal passage. However, when compared to observations at several sites, the temperature drop in the model is barely noticeable $\left(<1^{\circ} \mathrm{C}\right)$ and often limited to the immediate coastline. This could be due to the way WRF handles surface fluxes and vertical mixing, to inaccuracies in the sea surface temperatures, or to the 2-km horizontal resolution, which may not be fine enough to capture thermal changes on the subkilometer level, which is indicated by the observational analysis.

\section{f. Model sea-breeze characteristics}

The WRF Model does a reasonable job of representing the general characteristics of the Delaware Sea breeze. However, one of the advantages of using an atmospheric model like WRF to study the sea breeze is that insight into the sea-breeze dynamics can be gained from the improved spatial coverage of the model relative to observations. The output from the model's innermost domain covers most of the state of Delaware and half of the Delmarva Peninsula at 2-km resolution and provides a perfect dataset for looking at some of the complex sea-breeze dynamics. Adams (1997) characterized some of this complexity by categorizing sea-breeze fronts into three types for the Northern Hemisphere based on the prevailing wind direction: 
July 12, 2009: 17:00 GMT

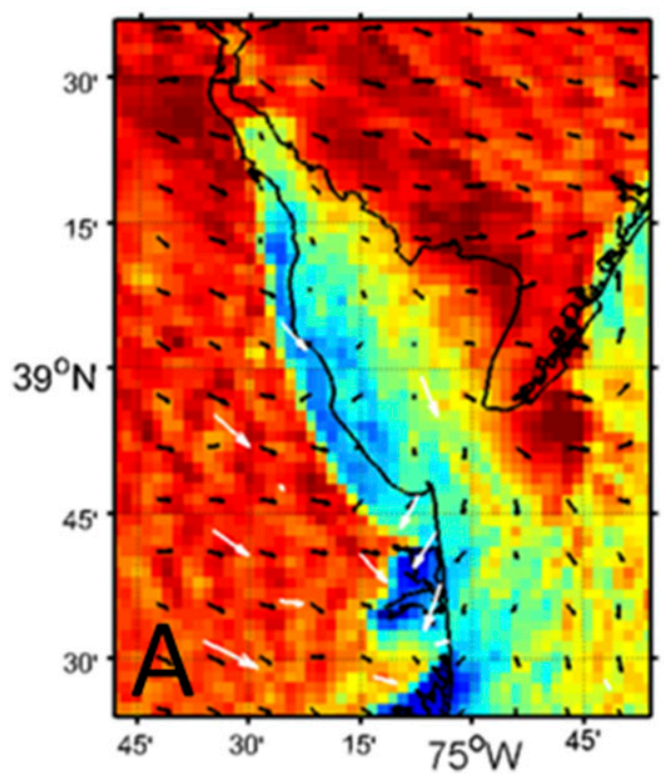

July 25, 2009: 17:00 GMT
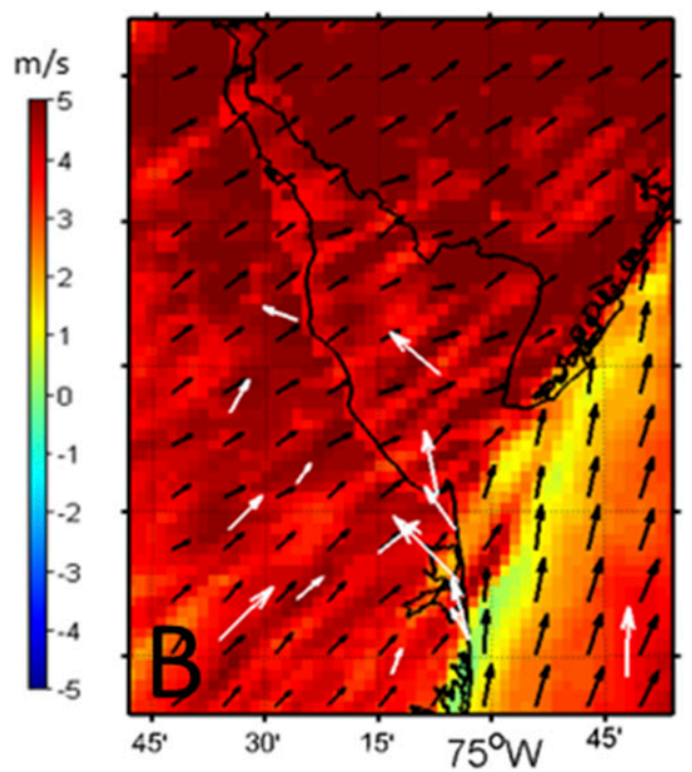

FIG. 9. WRF representation of a sea breeze. Modeled (black arrows) and observed (white arrows shown at $2 \times$ magnitude and extrapolated to $10 \mathrm{~m} \mathrm{AGL}$ ) wind vectors are plotted for two test cases showing (a) strong and (b) weak agreement. The magnitude of the $u$-component modeled wind is also plotted. The sharp gradient between offshore (red) and onshore (blue) winds indicates the location of the sea-breeze front.

backdoor (clockwise shift), corkscrew (counterclockwise shift), and pure (when synoptic winds are calm). A corkscrew sea breeze is more common in Delaware because of the persistence of southwest synoptic flow during the summertime (Hughes and Veron 2015). When the backdoor sea breeze occurs in Delaware, it develops in the presence of northwesterly wind, which is more aligned with the Delaware Bay coastline. Another key difference between the backdoor and corkscrew sea-breeze front for the Delaware sea breeze is that the corkscrew sea breeze is assisted by the Coriolis force while the backdoor sea breeze is hindered by it. Two case studies were selected that demonstrate the range of WRF's ability to simulate the details of the sea breeze (Fig. 9).

On 12 July 2009 WRF accurately simulated the development and movement of a classic backdoor sea breeze (Adams 1997) in terms of the wind direction shift (clockwise), the timing of the front, and the related temperature change. In addition, the observed and modeled data demonstrated early morning light synoptic winds that increased during the afternoon. A seabreeze front was observed to pass through $\mathrm{C} 3$ late in the morning (1500 UTC, 1100 EDT) and then passed over $\mathrm{S} 3$ approximately $2 \mathrm{~h}$ later. The observed temperature at $\mathrm{C} 3$ decreased by $5^{\circ} \mathrm{C}$, while farther inland, at $\mathrm{S} 3$, the decrease was only $2^{\circ} \mathrm{C}$. In the model, both stations shared the same grid cell because of the relatively coarse model resolution. WRF-simulated sea-breeze passage occurred at 1400-1500 UTC, which is similar to the time that it reached $\mathrm{C} 2$ and $\mathrm{C} 3$ in the observational record. However, there was no corresponding temperature drop in the model, although the temperature held steady for a few hours while temperatures increased at inland grid cells unaffected by the circulation. By 1700 UTC the model accurately simulated the regional winds (within $30^{\circ}$ ) at nearly every station including those influenced by the sea breeze (Fig. 9a).

In contrast, the WRF Model does not correctly simulate the classic corkscrew sea-breeze circulation (Adams 1997) on 25 July 2009 as represented in Fig. 9b. While the direction of the modeled and observed synoptic winds were in agreement in the early morning, the model failed to develop the sea-breeze front that formed in the morning hours. However, the model generated a wind shift from the southwest to the south just offshore of the Delaware coast, which is consistent with the development of a sea breeze (Fig. 9b). This feature, while not nearly as pronounced as the simulated sea-breeze circulation of 12 July 2009, persisted for several hours without reaching the coast. At 1700 UTC, there is only a $15^{\circ}-30^{\circ}$ difference in wind direction between the model and those observations that are unaffected by the sea breeze. The formation of the sea-breeze front just 
offshore in the model adds complexity to the comparison of the model and observed sea breezes.

\section{Discussion}

This is the first detailed characterization of the Delaware sea breeze using more than a handful of meteorological stations. One goal of this analysis was to create an algorithm that objectively identifies and detects seabreeze frontal passage over a range of stations across southern Delaware. The skill of the detection algorithm was investigated using synoptic maps and radar to ascertain when sea-breeze conditions were incorrectly identified from station observations. The analysis showed that incorrect sea-breeze identification was most likely to occur in the presence of complex and variable synoptic and/or mesoscale conditions. One example of such misidentification was associated with the passage of a backdoor or side door cold front, which can move through the region (west to east) in the opposite direction of most cold fronts. The changes associated with these fronts (e.g., drop in temperature or shift in wind direction) are very similar to what is observed from the passage of a seabreeze front. However, these synoptic-scale systems do not impact Delaware often (Hakim 1992) and probably cause a slight overestimate in the sea-breeze frequency, especially at inland stations. Occasionally, thunderstorm outflow also falsely triggered the detection of a sea breeze by the algorithm. It is possible that such an outflow could move toward and then combine with a stationary sea breeze causing it to move landward. Another source of error was attributed to shifting synoptic winds. If the winds closer to the coastline were affected by an offshore low pressure or high pressure system they may shift and falsely trigger detection of a sea breeze. To mitigate this, the detection algorithm requires the difference in the wind direction between a sample station and the reference station to be greater than $45^{\circ}$.

The observational sea-breeze detection algorithm characterized the timing and frequency of the Delaware sea breeze using observations from several meteorological stations in the region. The sea breeze was found to occur as frequently as $68 \%$ at the coast, but this high frequency decreases precipitously within the first kilometer of the coastline. On average, it appears that the sea-breeze frequency decreases $20 \%$ every $10 \mathrm{~km}$ inland from the coast. The Delaware sea breeze penetrates $40 \mathrm{~km}$ inland from the coastline less than $10 \%$ of the time. The Delaware sea breeze occurs in all seasons but, as is common in other areas that experience sea breeze, the highest occurrence is in the summer when the largest temperature gradients between land and sea surface temperatures are most common. This result is similar to what Sikora et al. (2010) found for the Chesapeake Bay breeze. Similar results were also found in an analysis of the sea breeze in São Paulo, Brazil, which indicated the year-round presence of the sea breeze (Perez and Silva Dias 2017). Although closer to the equator, São Paulo has a noticeable seasonality to the climatological surface temperature and cooler air temperatures over land resulting in a delay of the sea-breeze arrival time, which was also indicated with our study.

The Delaware sea breeze was observed to have strong frontal properties, leading to temperature changes of $3^{\circ}-5^{\circ} \mathrm{C}$, dewpoint temperature changes of $1^{\circ}-2^{\circ} \mathrm{C}$, wind speed changes of from -1 to $+2 \mathrm{~m} \mathrm{~s}^{-1}$ depending on proximity to the coastline, and wind direction changes of $45^{\circ}-180^{\circ}$. Sea breezes in this region were quite weak, especially if initiated early in the day, and there may be several initiating events before the sea breeze penetrates inland. The difference in temperature induced by the Delaware sea breeze was strongest and most persistent during the spring. This agrees with Bowers (2004) who indicated that cooler sea surface temperatures, relative to the inland daily maximum air temperatures, contribute to the temperature drop associated with the sea breeze in this region. Prevailing conditions preceding the arrival of a sea breeze in the late afternoon hours were often different than those in the morning including stronger near-surface winds (Hughes and Veron 2015) and warmer near-surface temperatures. On most classic sea-breeze days, the stations closest to the coast were typically warmer than the inland stations during the morning hours. These stations are located in developed areas, which are impacted by the urban heat island effect and they may also experience a modifying thermal effect from the relatively warm nearby ocean and inland bays.

The analysis of the Delaware sea breeze indicated that the sea breeze is quite complex in this region. For example, occasionally, a few stations detected evidence of sea-breeze-like conditions without clear signs of a frontal passage. When this happened, the wind direction shifted slowly to have an easterly (onshore) flow along with a gradual decrease in temperature with no similar changes observed farther inland. In addition, our analysis also suggested that sea-breeze conditions can also develop slowly without clear evidence when the front actually passed through a station, leading to the creation of a secondary classification of a weak sea breeze. The difference in the formation of classic and weak sea breezes results in two distinct set of changes in the surface temperature and wind speed and direction throughout the day. In addition, it is clear from our analysis that the Delaware sea breeze can act as two separate circulation systems that can converge, or remain independent. Both fronts may pass through the mouth of the Delaware Bay (over the Bay as well 
as over land at Lewes), which partially explains the complex spatial and temporal distribution of the wind over the Delmarva Peninsula, and the Delaware Bay (Muscarella et al. 2011). One or both fronts may also converge with the sea breeze coming from the Chesapeake Bay.

In agreement with studies from other regions (Fovell and Dailey 2001; Alpert and Rabinovich-Hadar 2003; Gilliam et al. 2004), we found evidence in the observations that Delaware sea-breeze fronts may be stalling and either dissipating or retrograding for hours before moving inland. When the front retrograded through a station, the temperature at that location quickly returned to what it was prior to the original passage of the front. These events suggest a near balance between the synoptic-scale and mesoscale forces. A third force, the Coriolis, causes the sea-breeze-induced winds to shift clockwise, often from the south-southeast to south, which weakens the landward flow of the marine air (Neumann 1977). However, when the sea-breeze-induced winds are from the northeast, the Coriolis effect can cause the winds to shift to the east, thus fully perpendicular to the coast, which may increase forward frontal movement. All of these factors influence the temperature drop caused by the sea breeze and may impact the potential development of the land breeze overnight (Yan and Anthes 1987).

Model simulations of the Delaware sea breeze were performed using WRF for 10 summers to explore the spatial features of the Delaware sea breeze. In agreement with observations, WRF frequently simulated the formation of a sea-breeze circulation along the Delaware coastline. Along the ocean coastline, the model seabreeze frequencies were $20 \%$ lower than those observed, while along the bay coastline the model produced sea breezes at the same frequency as that observed. The model was unable to demonstrate the sharp decline in sea-breeze frequency within the first kilometer of the coast because of the 2-km spatial resolution, but it accurately reproduced the significant decrease in sea-breeze frequency farther inland.

Occasionally, the model misrepresented synoptic features, which sometimes led to large errors in temperature and wind magnitude in comparison to observations. One possible cause of differences between the modeled and observed sea breezes may be the $20-\mathrm{km}$ resolution of sea surface temperatures that were ingested into the model, which was not high enough to capture local upwelling that is frequent along the southern coastline of Delaware during the summertime (Voynova et al. 2013). The lack of upwelling in the model domain results in a misrepresentation of the near-shore sea surface temperatures that may influence the origination location and development of a sea-breeze circulation.
In the presence of synoptic winds with a strong offshore flow, the modeled sea-breeze circulation often developed along the coast or just offshore and then moved landward causing a wind shift over the affected region. This is an important feature because a circulation that develops offshore has time to become well defined before reaching the coast (Asimakopoulos et al. 1999) and may lead to a large temperature drop, which is consistent with the classic sea breeze. The fronts that develop right along the coast show more gradual temperature and humidity changes, which is consistent with the "weak sea breeze" categorization. This distinction in frontal development location, which is clear in modeled data, is difficult to observe using meteorological stations as there are no station currently located nearshore (with $2 \mathrm{~km}$ of the coast but on the water). Available National Data Buoy Center stations are either located onshore at the coast, or 10-40 km offshore. However, it is important to note that, on days in this study on which a front was detected observationally at a station but not within its model cell equivalent, a sea-breeze circulation was visible within the domain more than $80 \%$ of the time.

\section{Conclusions}

The sea-breeze circulation is an important source of spatial variation in wind and temperature along Delaware's coastline. Although acknowledged as the primary source of wind variability in the region (Hughes and Veron 2015), the Delaware sea breeze has been understudied despite having impacts on society. Our analysis suggests that this variation is substantial, even on a scale of kilometers. At such a resolution, local variation in the land and sea surface including inlets and urbanization become increasingly important because of the impact coastal shape and land surface heating and roughness has on the wind. The Delaware Bay often has a significantly different sea surface temperature (usually warmer) than the nearby Atlantic Ocean, which can influence the development of the sea-breeze front along its coastline. There are also strong sea surface temperature gradients in and just outside the mouth of the Delaware Bay (Voynova et al. 2013), which can lead to the formation of a secondary sea breeze that originate from the Delaware Bay coast. Coastal locations such as Lewes, Delaware, can be affected by both fronts originating from the Delaware Bay and Atlantic Ocean.

As the location of the sea-breeze development appears to be very important in determining sea-breeze strength, future studies should explore the sensitivity of sea-breeze formation and propagation at subkilometer resolution. Modeling studies at this high resolution will provide insight into the dynamics of this highly variable phenomenon. 
In particular, studies of how sea-breeze development and movement is influenced by small variations in the land surface can be performed. In addition, new observations are needed at high spatial resolutions to characterize the interaction of the sea breeze with the land surface.

Further research is warranted to diagnose the impact of the Delaware sea breeze on the economy of coastal communities, including tourism, agriculture, and energy usage and production. Overall, better understanding of the dynamics of the competition between local-, meso-, and synoptic-scale atmospheric dynamics will improve understanding of local climate and improve its predictability. Enhanced knowledge of the details of the local sea breeze could also be beneficial to Delaware's coastal communities that rely heavily on the economic impact of the summertime tourist season.

Acknowledgments. This work was generously supported by the Delaware Sea Grant foundation, Project R/ETE-12. We also thank the Delaware Environmental Observing System, the National Data Buoy Center, and the National Centers for Environmental Prediction for providing observational and model-derived data.

\section{REFERENCES}

Abbs, D. J., and W. L. Physick, 1992: Sea-breeze observations and modeling: A review. Aust. Meteor. Mag., 41, 7-19.

Adams, E., 1997: Four ways to win the sea breeze game. Sailing World, March, 44-49.

Alpert, P., and M. Rabinovich-Hadar, 2003: Pre- and post-seabreeze frontal lines-A meso- $\gamma$-scale analysis over south Israel. J. Atmos. Sci., 60, 2994-3008, https://doi.org/10.1175/ 1520-0469(2003)060<2994:PAPFLM >2.0.CO;2.

Arrillaga, J. A., C. Yagüe, M. Sastre, and C. Román-Cascón, 2016: A characterisation of sea-breeze events in the eastern Cantabrian coast (Spain) from observational data and WRF simulations. Atmos. Res., 181, 265-280, https://doi.org/10.1016/ j.atmosres.2016.06.021.

Arritt, R. W., 1989: Numerical modeling of the offshore extent of sea breezes. Quart. J. Roy. Meteor. Soc., 115, 547-570, https:// doi.org/10.1002/qj.49711548707.

_ 1993: Effects of the large-scale flow on characteristic features of the sea breeze. J. Appl. Meteor., 32,116-125, https://doi.org/ 10.1175/1520-0450(1993)032<0116:EOTLSF $>2.0$. CO;2.

Asimakopoulos, D. N., C. G. Helmis, K. H. Papadopoulos, J. A. Kalogiros, P. Kassomenos, and M. Petrakis, 1999: Inland propagation of sea breeze under opposing offshore wind. Meteor. Atmos. Phys., 70, 97-110, https://doi.org/10.1007/s007030050027.

Atkins, N. T., and R. M. Wakimoto, 1997: Influence of the synopticscale flow on sea breezes observed during CaPE. Mon. Wea. Rev., 125, 2112-2130, https://doi.org/10.1175/1520-0493(1997) 125<2112:IOTSSF $>2.0 . \mathrm{CO} ; 2$.

Barbato, J. P., 1975: The sea breeze of the Boston area and its effect on the urban atmosphere. Ph.D. dissertation, Boston University, 223 pp.

Biggs, W. G., and M. E. Graves, 1962: A lake breeze index. J. Appl. Meteor., 1, 474-480, https://doi.org/10.1175/1520-0450(1962)001<0474: ALBI $>2.0 . \mathrm{CO} ; 2$.
Bigot, S., and O. Planchon, 2003: Identification and characterization of sea breeze days in northern France using singular value decomposition. Int. J. Climatol., 23, 1397-1405, https://doi.org/ 10.1002/joc. 940 .

Borne, K., D. Chen, and M. Nunez, 1998: A method for finding sea breeze days under stable synoptic conditions and its application to the Swedish west coast. Int. J. Climatol., 18, 901-914, https://doi.org/10.1002/(SICI)1097-0088(19980630)18:8<901:: AID-JOC295>3.0.CO;2-F.

Bornstein, R. D., and W. T. Thompson, 1981: Effects of frictionally retarded sea breeze and synoptic frontal passages on sulfur dioxide concentrations in New York City. J. Appl. Meteor., 20, 843-858, https://doi.org/10.1175/15200450(1981)020<0843:EOFRSB > 2.0.CO;2.

Bowers, L. A., 2004: The effect of sea surface temperature on sea breeze dynamics along the coast of New Jersey. M.S. thesis, Dept. of Oceanographic Studies, Rutgers, The State University of New Jersey, 148 pp.

Chen, F., and J. Dudhia, 2001: Coupling an advanced land surfacehydrology model with the Penn State-NCAR MM5 modeling system. Part I: Model implementation and sensitivity. Mon. Wea. Rev., 129, 569-585, https://doi.org/10.1175/15200493(2001)129<0569:CAALSH > 2.0.CO;2.

_ S. Miao, M. Tewari, J.-W. Bao, and H. Jusaka, 2011: A numerical study of interactions between surface forcing and sea breeze circulations and their effects on stagnation in the greater Houston area. J. Geophys. Res., 116, D12105, https:// doi.org/10.1029/2010JD015533.

Coccolo, S., J. Kämpf, J. L. Scartezzini, and D. Pearlmutter, 2016: Outdoor human comfort and thermal stress: A comprehensive review on models and standards. Urban Climate, 18, 33-57, https://doi.org/10.1016/j.uclim.2016.08.004.

Dudhia, J., 1989: Numerical study of convection observed during the winter monsoon experiment using a mesoscale twodimensional model. J. Atmos. Sci., 46, 3077-3107, https:// doi.org/10.1175/1520-0469(1989)046<3077:NSOCOD>2.0.CO;2.

Fett, R. W., and P. M. Tag, 1984: The sea-breeze-induced coastal calm zone as revealed by satellite data and simulated by a numerical model. Mon. Wea. Rev., 112, 1226-1233, https:// doi.org/10.1175/1520-0493(1984)112<1226:TSBICC > 2.0.CO;2.

Fovell, R. G., 2005: Convective initiation ahead of the sea-breeze front. Mon. Wea. Rev., 133, 264-278, https://doi.org/10.1175/MWR-2852.1. - and P. S. Dailey, 2001: Numerical simulation of the interaction between the sea-breeze front and horizontal convective rolls. Part II: Alongshore ambient flow. Mon. Wea. Rev., 129, 2057-2072, https://doi.org/10.1175/15200493(2001)129<2057:NSOTIB > 2.0.CO;2.

Franchito, S. H., V. B. Rao, J. L. Stech, and J. A. Lorenzzetti, 1998: The effect of coastal upwelling on the sea-breeze circulation at Cabo Frio, Brazil: A numerical experiment. Ann. Geophys., 16, 866-871, https://doi.org/10.1007/s00585-998-0866-3.

Gahmberg, M., H. Savijärvi, and M. Leskinen, 2010: The influence of synoptic scale flow on sea breeze induced surface winds and calm zones. Tellus, 62A, 209-217, https://doi.org/10.1111/ j.1600-0870.2009.00423.x.

Giannaros, T. M., D. Melas, I. A. Daglis, I. Keramitsoglou, and K. Kourtidis, 2013: Numerical study of the urban heat island over Athens (Greece) with the WRF Model. Atmos. Environ., 73, 103-111, https://doi.org/10.1016/j.atmosenv.2013.02.055.

Gilliam, R. C., S. Raman, and D. D. S. Niyogi, 2004: Observational and numerical study on the influence of large-scale flow direction and coastline shape on sea-breeze evolution. Bound.-Layer Meteor., 111, 275-300, https://doi.org/10.1023/B:BOUN.0000016494.99539.5a. 
Hakim, G. J., 1992: The eastern United States side-door cold front of 22 April 1987: A case study of an intense atmospheric density current. Mon. Wea. Rev., 120, 2738-2762, https://doi.org/ 10.1175/1520-0493(1992)120<2738:TEUSSD > 2.0.CO;2.

Hong, S.-Y., Y. Noh, and J. Dudhia, 2006: A new vertical diffusion package with explicit treatment of entrainment processes. Mon. Wea. Rev., 134, 2318-2341, https://doi.org/10.1175/MWR3199.1.

Hu, X.-M., J. W. Nielsen-Gammon, and F. Zhang, 2010: Evaluation of three planetary boundary layer schemes in the WRF Model. J. Appl. Meteor. Climatol., 49, 1831-1844, https://doi.org/ 10.1175/2010JAMC2432.1.

Hughes, C. P., and D. E. Veron, 2015: Characterization of low-level winds of southern and coastal Delaware. J. Appl. Meteor. Climatol., 54, 77-93, https://doi.org/10.1175/JAMC-D-14-0011.1.

Kain, J. S., and M. Fritsch, 1993: Convective parameterization for mesoscale models: The Kain-Fritsch scheme. The Representation of Cumulus Convection in Numerical Models, Meteor. Monogr., No. 46, Amer. Meteor. Soc., 165-170.

Kalnay, E., and Coauthors, 1996: The NCEP/NCAR 40-Year Reanalysis Project. Bull. Amer. Meteor. Soc., 77, 437-471, https:// doi.org/10.1175/1520-0477(1996)077<0437:TNYRP>2.0.CO;2.

Keeler, J. M., and D. A. R. Kristovich, 2012: Observations of urban heat island influence on lake-breeze frontal movement. J. App. Meteor. Climatol., 51, 702-710, https://doi.org/10.1175/ JAMC-D-11-0166.1.

Khan, B. A., 2010: Sea breeze circulation in the Auckland region: Observational data analysis and numerical modeling. Ph.D. thesis, University of Canterbury, $262 \mathrm{pp}$.

Kozo, T. L., 1982: An observational study of sea breezes along the Alaskan Beaufort Sea coast: Part I. J. Appl. Meteor., 21, 891-905, https://doi.org/10.1175/1520-0450(1982)021<0891: AOSOSB $>2.0 . \mathrm{CO} ; 2$.

Laird, N. F., D. A. R. Kristovich, X.-Z. Liang, R. W. Arritt, and K. Labas, 2001: Lake Michigan lake breezes: Climatology, local forcing, and synoptic environment. J. Appl. Meteor., 40, 409-424, https://doi.org/10.1175/1520-0450(2001)040<0409: LMLBCL $>2.0$. CO;2.

Mazon, J., J. I. Rojas, J. Jou, A. Valle, D. Olmeda, and C. Sanchez, 2015: An assessment of the sea breeze energy potential using small wind turbines in peri-urban coastal areas. J. Wind Eng. Ind. Aerodyn., 139, 1-7, https://doi.org/10.1016/j.jweia.2015.01.002.

Mlawer, E. J., S. J. Taubman, P. D. Brown, M. J. Iacono, and S. A. Clough, 1997: Radiative transfer for inhomogeneous atmospheres: RRTM, a validated correlated- $k$ model for the longwave. J. Geophys. Res., 102, 16 663-16 682, https://doi.org/ 10.1029/97JD00237.

Muscarella, P. A., N. P. Barton, B. L. Lipphardt Jr., D. E. Veron, K. C. Wong, and A. D. Kirwan Jr., 2011: Surface currents and winds at the Delaware Bay mouth. Cont. Shelf Res., 31, 12821293, https://doi.org/10.1016/j.csr.2011.05.003.

Neumann, J., 1977: On the rotation rate of the direction of sea and land breezes. J. Atmos. Sci., 34, 1913-1917, https://doi.org/ 10.1175/1520-0469(1977)034<1913:OTRROT>2.0.CO;2.

NOAA, 2018: Northeast regional land cover change report: 19962010. NOAA Rep., 13 pp., https://coast.noaa.gov/data/digitalcoast/ pdf/landcover-report-northeast.pdf.

Papanastasiou, D. K., and D. Melas, 2009: Climatology and impact on air quality of sea breeze in an urban coastal environment. Int. J. Climatol., 29, 305-315, https://doi.org/10.1002/joc.1707.

_,$\ldots$, and I. Lissaridis, 2010: Study of wind field under sea breeze conditions; an application of WRF Model. Atmos. Res., 98, 102-117, https://doi.org/10.1016/j.atmosres.2010.06.005.
Perez, G. M. P., and M. A. F. Silva Dias, 2017: Long-term study of the occurrence and time of passage of sea breeze in São Paulo, 19602009. Int. J. Climatol., 37, 1210-1220, https://doi.org/10.1002/joc.5077.

Physick, W. L., 1980: Numerical experiments on the inland penetration of the sea breeze. Quart. J. Roy. Meteor. Soc., 106, 735746, https://doi.org/10.1002/qj.49710645007.

Porson, A., D. G. Steyn, and G. Schayes, 2007: Sea breeze scaling from numerical model simulations. Part I: Pure sea breezes. Bound.-Layer Meteor., 122, 17-29, https://doi.org/10.1007/ s10546-006-9090-4.

Rife, D. L., C. A. Davis, Y. Liu, and T. T. Warner, 2004: Predictability of low-level winds by mesoscale meteorological models. Mon. Wea. Rev., 132, 2553-2569, https://doi.org/10.1175/MWR2801.1.

Ryznar, E., and J. S. Touma, 1981: Characteristics of true lake breezes along the eastern shore of Lake Michigan. Atmos. Environ., 15, 1201-1205, https://doi.org/10.1016/0004-6981(81)90311-5.

Savijärvi, H., and M. Alestalo, 1988: Sea breeze over a lake or gulf as the function of the prevailing flow. Beitr. Phys. Atmos., 61, 98-104.

Sikora, T. D., G. S. Young, and M. J. Bettwy, 2010: Analysis of the western shore Chesapeake Bay bay-breeze. Natl. Wea. Dig., 34, 55-65, http://nwafiles.nwas.org/digest/papers/2010/Vol34No1/ Pg55-Sikora-etal.pdf.

Simpson, J. E., 1994: Sea Breeze and Local Winds. Cambridge University Press, $234 \mathrm{pp}$.

Skamarock, W. C., and J. B. Klemp, 2008: A time-split nonhydrostatic atmospheric model for weather research and forecasting applications. J. Comput. Phys., 227, 3465-3485, https://doi.org/10.1016/ j.jcp.2007.01.037.

Srebric, J., M. Heidarinejad, and J. Liu, 2015: Building neighborhood emerging properties and their impacts on multi-scale modeling of building energy and airflows. Build. Environ., 91, 246-262, https://doi.org/10.1016/j.buildenv.2015.02.031.

Stauffer, R. M., and Coauthors, 2015: Bay breeze influence on surface ozone at Edgewood, MD during July 2011. J. Atmos. Chem., 72, 335-353, https://doi.org/10.1007/s10874-012-9241-6.

Thompson, W. T., T. Holt, and J. Pullen, 2007: Investigation of a sea breeze front in an urban environment. Quart. J. Roy. Meteor. Soc., 133, 579-594, https://doi.org/10.1002/qj.52.

Tijm, A. B. C., A. J. Van Delden, and A. A. M. Holtslag, 1999: The inland penetration of sea breezes. Contrib. Atmos. Phys., 72, 317-328.

U.S. Census Bureau, 2011: 2010 census redistricting data (Public Law 94-171): Summary file. Tech. Doc., 199 pp.

Veron, D. E., J. F. Brodie, Y. A. Shiraz, and J. R. Gilchrist, 2018: Modeling the electrical grid impact of wind ramp-up forecasting error offshore in the mid-Atlantic region. J. Renewable Sustainable Energy, 10, 013308, https://doi.org/10.1063/1.4990684.

Voynova, Y. G., M. J. Oliver, and J. H. Sharp, 2013: Wind to zooplankton: Ecosystem-wide influence of seasonal winddriven upwelling in and around the Delaware Bay. J. Geophys. Res. Oceans, 118, 6437-6450, https://doi.org/10.1002/2013JC008793.

Whitney, M. M., and R. W. Garvine, 2006: Simulating the Delaware Bay buoyant outflow: Comparison with observations. J. Phys. Oceanogr., 36, 3-21, https://doi.org/10.1175/JPO2805.1.

Xian, Z., and R. A. Pielke, 1991: The effects of width of landmasses on the development of sea breezes. J. Appl. Meteor., 30, 1280-1304, https://doi.org/10.1175/1520-0450(1991)030<1280: TEOWOL $>2.0 . \mathrm{CO} ; 2$.

Yan, H., and R. A. Anthes, 1987: The effect of latitude on the sea breeze. Mon. Wea. Rev., 115, 936-956, https://doi.org/10.1175/ 1520-0493(1987)115<0936:TEOLOT>2.0.CO;2. 